\title{
AIR FREIGHT AND AIR EXPRESS
}

\author{
Peter W. Wilson*
}

Air express service is provided the public by Railway Express Agency, Inc., pursuant to a uniform contract ${ }^{1 *}$ with the multiple-service certificated airlines filed with and approved ${ }^{2}$ by the Civil Aeronautics Board. ${ }^{3}$ Air express moves under the tariffs and billing of REA. It, rather than the airline, occupies the relationship of carrier to the shipper. Under the contracts REA solicits business, collects shipping charges, renders pick-up and delivery service, routes the traffic, supervises transfers, does the accounting, handles claims, and performs all functions necessary for the conduct of the business other than loading and unloading planes and flying them between airports. The contracts provide for a pooling arrangement. After the deduction from gross revenues of the out-of-pocket expenses of REA, the balance is distributed $871 / 2$ per cent to the airlines and $12 \frac{1}{2}$ per cent to REA.

Air freight service is rendered by the certificated multiple-service carriers, the newly certificated all-cargo carriers, and certain noncertificated and contract carriers under their own individual tariffs and billing. It is conducted independently of REA. Air freight is essentially a post-war development. It received its principal impetus from returned veterans who with surplus military aircraft launched the first serious effort to attract volume traffic to the air. American Airlines filed, on September I4, I944, ${ }^{5}$ the first tariff for the carriage of air freight since the enactment of the Civil Aeronautics Act of $193^{\circ} .^{\circ}$ It seems doubtful that the multiple-service carriers would have spent much of their energies in that direction had it not been for the advent of the noncertificated cargo carriers. Certainly, little progress was evident until their competitive influence was felt.

Air freight in terms of ton-miles carried has made tremendous strides in a relatively short time. ${ }^{7}$ Measured in terms of financial returns to the carriers much re-

*A.B. I928, Mt. St. Mary's College; LL.B. I931, Fordham University Law School. Member, New York bar. General Attorney, Railway Express Agency, Inc.

${ }^{1}$ Hereinafter referred to as REA.

12 REA has a separate agreement with each airline, uniform in all respects with each other agreement except for name of airline, routes embraced, and effective date.

${ }^{2}$ Railway Express Agreements, 4 C. A. B. I57 (1943) separate orders dated March 2, 1943, March 12, I943, and March 31, I943.

${ }^{3}$ Hereinafter referred to as the Board.

- In I948 gross air express revenue amounted to $\$ 18,503,926.29$. Expenses aggregated $\$ 6,551,911.05$. From the balance remaining for distribution the airlines received $\$ 10,458,013.32$ and REA $\$ 1,494,001.92$.

Transcontinental and Western $\mathrm{Air}$, Inc. filed an air freight tariff on June I, 1945 . Other filings soon followed, and at present practically all carriers have filed air freight tariffs with the Board.

${ }^{\circ} 52$ STAT. 977 (1938), 49 U. S. C. $\$ 401$ (1946).

7 Between August 1945 and October 1946 the monthly volume of scheduled air freight rose from 211,608 to $2,054,467$ ton-miles. In 1947 the ton-miles of freight carried by both certificated and noncertificated carriers totaled $84,170,583$. In 1948 it reached a total of II5,962,035 ton-miles. 
mains to be done. ${ }^{8}$ Air freight rates have been and, it would seem, are still far from being compensatory. ${ }^{9}$ In the Air Freight Rate Investigation ${ }^{10}$ the Board established minimum rates to halt a rate war raging between the multiple-service airlines and the noncertificated cargo carriers. Airline management is now becoming alerted to the realities of destructive rate competition. The Class Rate Investigation ${ }^{11}$ recently inaugurated by the Board may result in closing out the "bargain sales" presently available to the shipping public. ${ }^{12}$ It will, in any event, mark the second step in the érection of a more realistic air property rate structure.

Analysis of air freight and air express problems requires preliminary explanation of the status of REA in air and other forms of transportation. REA has been engaged in the carriage of property by air as an indirect carrier for over twenty years. It is also a common carrier express company subject to the provisions of the Interstate Commerce Act. ${ }^{13}$ It utilizes practically all forms of transportation in providing a coordinated national transportation system for the carriage of property by air, rail, truck, and, in some instances, by steamboat. It neither owns nor operates aircraft or other intercity conveyances except motor vehicles. It does not transport passengers.

${ }^{8}$ Of the fourteen applicants in the Air Freight Case five had become bankrupt by the fall of 1948 and three others had ceased operations. Of the survivors all showed an unbroken record of financial losses.

- The Report to Stockholders on the Annual Meeting of United Air Lines, Inc., April 12, 1949, contained the following statement:

"As to the development of air freight ... every pound of freight we carry on United Air Lines in an all-cargo plane has paid for the gas, oil and pilot pay. It has not produced for you as stockholders one cent of added cash and far from a profit.

"We are carrying freight for about I7 cents a ton-mile. I wanted to make sure in our annual report that this was emphasized, because I observe publicity releases in newspapers that air cargo has increased 700 per cent. It would be natural for you to assume that such an increase would benefit you as a stockholder. I want to make it clear that now and for some time in the future, until rates are increased, you should pay no attention to reports on cargo increases. We are going through a highly competitive era with certain cargo operators. We are trying to do our best to compete and not lose cash. Let me just leave one thought with those who may be excitcd about air cargo. Cargo has a place in air transportation at much higher rates than we now are charging and probably commodities of great intrinsic value or high emergency value will move that way, but we are whistling in the dark when we say we can do it for I7 cents."

${ }^{10} 9$ C. A. B. 340 (1948). This involved a general investigation by the Board of air freight rates, as a result of which an order was issued establishing minimum rates for general commoditics at 16 cents a ton-mile for the first 1,000 ton-miles in any one shipment and 13 cents a ton-mile thereafter.

12 Docket No. 3665 , Order Serial No. E-2486, February 21, I949.

${ }^{12}$ In an address before The Association of the Bar of the City of New Yark on March 23, 1949,

Hon. Joseph J. O'Connell, Jr., Chairman of the Civil Aeronautics Board, stated:

"With respect to the freight rate investigation, our objective is to try to establish a pattern of rates in this youngest branch of air transportation which will permit the maximum development of the market and at the same time provide fair compensation for the carricrs. There is a growing volume of evidence that this cannot be successfully done under the present tariff structure pieced out here and there by commodity and so-called back-haul rates. The Board is not wedded to the idea of a class rate structure. On the other hand, I, at least, am wedded to the idea that the freight business should be entirely self-supporting to the end that it may decrease and not increase the level of subsidy required."

The following appears in the dissenting opinion of Member Jones in the Air Freight Case:

"Such rates ( 13 to 16 cents per ton-mile) have been specifically recognized by the Board as being uneconomic, and every effort has been and is being made to insure that actual levels will be held at some point substantially above the legal minimum."

1354 Stat. 899 (I940), 49 U. S. C. §I (I946). 
Following the enactment of the Civil Aeronautics Act it applied to the Board (Authority) ${ }^{14}$ for a "grandfather" certificate of public convenience and necessity under Section $40 \mathrm{O}(\mathrm{e})$ of the Act. The Board held that it was engaged in the business of transporting property by air as a common carrier and was included in the definition of "air carrier" as set forth in Section I(2) of the Act. ${ }^{15}$ The Board concluded, however, that REA's air operations were not such as to require a certificate and relieved it temporarily from the requirements of Section $401(a)$ to the extent necessary to enable it, without obtaining a certificate, to engage in the operations conducted by it with respect to the transportation of property by air pursuant to the contracts it had with the airlines. This exemption was subsequently amended in respects not here material. ${ }^{16}$ In the Air Freight Forwarder Case ${ }^{17}$ the Board continued in effect this exemption, directed the negotiation of a revised air express agreement embodying certain suggestions of the Board, ${ }^{18}$ and deferred final action on its applications to engage in air freight operations and to act as an air freight forwarder until the completion of the directed contract negotiations. ${ }^{19}$

In approaching a discussion of air freight and air express it is pertinent to point out that until the filing of American's air freight tariff the carriage of property by air had been limited to the service provided by REA. Air express by contract definition included all property other than passenger's baggage and mail. The Civil Aeronautics Act makes no distinction between, nor in fact any reference to, air express and air freight. Neither term is found in the Act. References are to "property" only. ${ }^{20}$ The certificates of public convenience and necessity issued to the multiple-service airlines authorize the engagement "in air transportation with respect to persons, property and mail." The certificates recently issued to certain all-cargo carriers also authorize the engagement in air transportation with respect to property. The original and amended exemption issued to REA authorized the transportation of property. The authority now enjoyed by the air freight forwarders is with reference to the transportation of property.

What then is the distinction between air freight and air express? To paraphrase

24 Title changed from Civil Aeronautics Authority to Civil Aeronautics Board by Presidential Reorganization Plan No. IV in I940.

${ }^{15}$ Railway Express Agency, Inc., Grandfather Certificate Case, 2 C. A. B. 53I (I94I).

${ }^{10}$ Order Serial No. 5149, September 3, 1946.

${ }^{27}$ Docket No. 681, et al., decided September 8, I948.

${ }^{18}$ The Board suggested that the carriers make a charge against REA for carrying air express which would cover their costs and insure them a reasonable margin of security. Also that the tariff rates to be charged the public for air express should be determined and filed by REA. Air express rates are now fixed by the airlines. See note 30 , infra.

${ }^{10}$ The Board stated: "However, since successful operation of the services of REA which we have found to be in the public interest is dependent upon the negotiation of a satisfactory revised air. express agreement pursuant to the negotiations we have directed, we will, as heretofore pointed out, defer final action on REA'S request to handle air freight and act as an air freight forwarder." The Board's decision in the Air Freight Forwarder Case is now on review before the United States Court of Appeals for the Seventh Circuit, American Airlines, Inc., et al. v. Civil Aeronautics Board, No. 9739. The petitioners contend inter alia that the Board exceeded its statutory power in directing that REA negotiate with the airlines new air express agreements containing specific provisions prescribed by the Board.

${ }^{20}$ See Sections I (20), (2I), 404(a), (b), I002(e), and Iro7 (j). 
one authority, air freight is air express at below cost rates. ${ }^{21}$ The necessity, or rather the occasion, to separate the air transportation of property into classifications apparently not intended by the framers of the Act did not arise until the Air Freight Case. $^{22}$ In that case some of the applicants urged that the authorizations issued in the various "grandfather" cases used the term "property"; and that the record of the certificated airlines showed carriage of but baggage and express, and thus their authority was limited to those activities. The Board disposed of the argument as follows:

The term "property" used in certificates of public convenience and necessity is broad and general in scope. It includes the right to carry freight. In one of the earliest cases on "grandfather" certificates ${ }^{23}$ a carrier requested a provision in its certificate that would construe the authorization to carry persons, property, and mail to include the right to carry all classes of traffic capable of being carried by aircraft. This Board said that: "The terms 'persons,' 'property,' and 'mail' are broad enough to include all classes of traffic which may be carried by airplane."

Accordingly, we hold as a matter of law, that any carrier authorized by its certificate to carry property is thereby authorized to carry any kind of property including baggage, express, and freight.

This language appears in both the tentative ${ }^{24}$ and final decisions in that case. Yet, in the final decision, the Board, although authorizing the carriers it certificated to engage in air transportation with respect to "property," specifically prohibited them from carrying "property" shipped by REA.

Such law as there is to be found on the subject of the legal distinction between air freight and air express is contained in the decisions of the Board in the Air Freight Case and the Air Freight Forwarder Case. In its decision in the former case the Board related that several of the applicants had challenged the authority of the certificated airlines to transport freight. Then follows this significant footnote.

"Freight" is here distinguished as property moved in equipment devoted entirely to property; "express" is considered to be property transported in equipment scheduled primarily for passenger transportation.

It is not clear whether this was the Board's conception of the difference between the two services or a summarization by it of the contention of the advocates of the theory referred to above. In either case the distinction lacks merit. However valid such a distinction may be in surface transportation, it has no application in air transportation. Express is that type of property which traditionally has used the fastest

${ }^{21}$ Wayne W. Parrish, Editor, American Aviation, editorial of January 15, 1949, reads in part:

"In clearer perspective, too, is the composition of air cargo or air freight. Actually it is air expressthe same type of shipments that have been transported by air for 15 or 20 years. The one big difference is a far greater volume. No really new field of air cargo has been developed since the war in term of types of shipments. Lower rates made possible by a combination of more cficient airplanes, plus an apparent willingness to operate at below cost, made available a larger volume of the same general type of what comprises the average express shipment."

${ }^{22}$ Dockets Nos. 8 10 et al. and 730 et al., decided July 29, 1949 .

${ }^{23}$ American Air, Grandfather Certificate, I C. A. B. 105 (1939).

21 Adopted April 25, r949, E-2759. 
means of transportation. In surface transportation the passenger vehicle ordinarily furnishes the swiftest mode of carriage. That does not follow in air transportation. A cargo plane which makes no intermediate stops or but a few such stops can traverse the same distance in the same or better time than a passenger plane making frequent stops en route to receive or discharge passengers and mail. Even transcontinental cargo planes can accomplish the same result in so far as delivery to consignees is concerned. Additionally, their departure time which is usually after the close of the business day is almost always better suited to shippers' requirements.

In the Air Freight Forwarder Case, which involved the applications of REA and some seventy-eight forwarder applicants to engage indirectly in the air transportation of property, the Board discussed air express at length. It endeavored to distinguish it from air freight. The net result was a conclusion that: "The difference between air express and air freight lies principally in the ground and accessorial services provided and in the amount of the rates charged shippers for the respective services." It is interesting to note that the distinction thus made, other than the rate differential, relates not to the air phase of the service but to the ground handling aspects. The Board could find no real difference between the air service afforded express and the air service given freight. It found in fact that: "Air freight frequently moves on the same planes with air express and the airport to airport transit time is often the same." The Board discussed at length the various ground service incidents of air express service, such as substituted surface transportation in cases of flight interruptions, the provision of special pick-up and delivery service, and other expedited features of the service, all of which were concerned with the ground service performed by REA prior and subsequent to the intercity air movement. It pointed out that:

There is not as much difference in the speeds at which different types of planes operate, point to point, as there is between the speeds of freight and express trains but there is an extremely high ratio of time that air express is in a ground status as compared to the time that it is actually in air.

It does not appear from the record in that case, nor is it a fact, that air freight is in a ground status to any lesser extent than air express. The Board acknowledged that:

It is true that air express cannot be distinguished from air freight by size or content of package, that air express is not necessarily and exclusively carried in passenger plane service while air freight moves only in slower all-cargo planes, that sometimes the time in transit of air freight equals that of air express, and that, so far as the carrier is concerned, it is sometimes difficult to determine what cargo should go as air express and what as air freight.

In denying REA air freight authority, the Board stated that an element of competition would always exist between air freight and air express, and that the competitive benefits resulting therefrom would best be preserved if the efforts of the parties dealing in each of these services were not divided, and if the functions and facilities 
for dealing in or with both were not commingled in one agency. The multipleservice carriers are permitted to handle both air express and air freight in the same planes and with the same facilities. The Board has yet to find any vice in their rendition of both coach and de luxe passenger service. ${ }^{25}$ Specialization in but one phase of air transportation has been given compulsory virtue only in the cases of REA and the certificated cargo carriers. With respect to the successful applicants in the Air Freight Forwarder Case other than REA, no separation or limitation of activities was imposed. They are free to conduct conventional freight forwarder service and also to provide expedited service of the same character as that rendered by REA in air express. At least one of the successful forwarder applicants is now rendering a service comparable to air express at rates higher than those charged for air express. ${ }^{28}$

The Board appreciates that both air express and air freight are carried in the same equipment and that there is relatively little difference in the air transit time of the two services. It justifies its position in this manner:

Pursuant to our decision here, the only legal distinction that will exist between air express and air freight will be that air express will move under the terms specified by the air express agreements and will have space priority over air freight.

It will be noted that nothing is said as to the medium of carriage and that no pretense is made that the distinction stated is one presently existing. In both the Air Freight Forwarder Case and the Air Freight Rate Case exhibits ${ }^{27}$ were introduced and testimony ${ }^{28}$ were adduced that not only was air express not given priority over air freight but that in practice parity, and sometimes priority, was in many instances given to air freight by the multiple-service carriers. The Examiner in the Air Freight Forwarder Case reported that air express is "ordinarily" given loading preference. ${ }^{29}$

Prior to the filing of American Airlines' air freight tariff on October x, 1944, no distinction existed between air express and air freight. All air cargo was carried as air express regardless of weight or size of shipment or length of haul. The air express agreements pursuant to which the multiple-service airlines and REA conduct the business of transporting property by air provide for the engagement by the parties "in operating an air express transportation business." The term "Express Business" as used therein is defined as being "all traffic of whatsoever nature designated by the shipper for carriage by air." The traffic handled under the air express

\footnotetext{
${ }^{25}$ Northwest Airlines now proposes to operate a third type of passenger service at fares between those charged on Stratocruisers and those of coach service. New York Times, August 21, 1949, p. 58, col. 2. The Board, on September 27, 1949, suspended and ordered an investigation of the tariffs covering this three-level fare structure.

${ }^{26}$ The so-called "blue-ribbon" service of Emery Air Frcight Corporation.

${ }^{27}$ REA Exs. Z-Ig and Oakland No. IV in Docket No. 681 et al. and REA Exhibit No. 37 in Docket No. 1705 et al.

${ }^{23}$ Testimony of witnesses Cummings and Lickteig in Docket No. 681 et al. Tr. 2649 and 2650 in Docket No. 1705 et al.

${ }^{20}$ Report of J. Earl Cox, Examiner, April 2r, 1948.
} 
agreements has been essentially a small package business. This has been the result of rates rather than any limitation of the service itself. Planeload shipments, shipments weighing many thousands of pounds, livestock, and shipments of the type now moving in air freight have moved and still move by air express. Had not the airlines insisted upon the maintenance of high express rates ${ }^{30}$ the volume of air express and the average weight of air express shipments would undoubtedly have been increased.

Only one type of property service has been conducted under the air express agreements. The term "air express" was chosen as its trade designation. It seems to have been a happier choice than "air freight" which carries with it the implication of slowness or, at least, deferment to some superior service. The parties contemplated, however, the possibility that at some future time a slower or secondary service might be established. They provided in their agreement that:

It is contemplated that the Air Company and all air companies having similar agreements with the Express Company may establish various types of air express service based upon the time consumed in the transportation of express matter, such as expedited air express, freight or deferred express and other services which will permit the shipper to choose a particular type in accordance with his needs. The Express Company agrees that in exerting itself in all proper ways to make said business satisfactory, it will promote the sale of each and every type of service so adopted by the Air Company or the other air companies having similar agreements with the Express Company.

No utilization of this provision was made until April of 1946 . Following the inauguration of air freight service by American Airlines and a number of other lines, Northwest Airlines and REA entered into an agreement, dated April 12, 1946, providing for the operation of an air freight business which, according to its terms, was to be a lower cost service subject to deferment to the carriage of mail, passengers, and air express. Especially significant is the fact that the parties adopted deferment of freight to express as the distinguishing characteristic of the service, appreciating, it would appear, the necessity for such a difference because of the wide variance in rates. ${ }^{31}$ The Board disapproved the agreement ${ }^{32}$ on the ground that it violated the terms of REA's exemption orders. It ruled that they limited REA to operations conducted pursuant to the air express agreements. The Board in its order of disapproval did not discuss the characteristics of air freight and air express. It also failed to comment on the contention of the parties to the air freight agreement that it merely implemented the "contemplation" clause of the air express agreements quoted above. ${ }^{33}$

${ }^{30}$ Under the Air Express Agreement the airlines fix the air express rates. The record in the Air Freight Forwarder Case indicates that they have resisted effort by REA to reduce rates.

${ }^{31}$ The rates were to be about 30 cents per ton-mile as contrasted with the air express rate of approximately $6 \mathrm{I}$ cents per ton-mile.

${ }^{32}$ Orders Serial Number E-I165, January 28, 1948.

${ }^{33}$ The Board found that:

"I. Railway Express is authorized to engage in air transportation pursuant to the terms of an cxemption order dated March I3, I94I (Serial, No. 94I) as amended on September 3, I946 (Serial No. 5149) which permits operations pursuant to certain air express contracts, approved by 
In the Air Freight Forwarder Case the Board has outlined what it conceives will be the legal distinction between air freight and air express if its direction to negotiate a revised air express agreement is successfully carried out. The distinction will be priority of carriage for air express. That distinction does not exist now in all cases. If there is to continue to exist a substantial difference between air express and air freight rates, ${ }^{34}$ priority should be mandatory. Serious questions of discrimination otherwise may arise. ${ }^{35}$

The decisions referred to herein bespeak no unawareness on the part of the Board that in basic essentials there is little, if any, real difference between air freight and air express as far as air carriage is concerned. They bring about a rather extraordinary situation. The effect seems to be that air express is to be property which is handled by REA. All other property is to be air freight. Expedited ground handling of the latter apparently will not alter its status. It can be assumed that with improved ground handling on the part of the direct air carriers and the forwarders the difference in the over-all speed from shipper to consignee as between air express and air freight will gradually disappear. That being so, the question arises whether there should be two air property services. Would not the industry make greater progress if there was but one cargo service in which all carriers, both direct and indirect, could participate? The multiple-service carriers at one time expressed an inclination for such an arrangement. ${ }^{36}$

The Board's expressed policy with respect to air property transportation as concerns REA may flow from a conviction on its part that regardless of considerations of public convenience and necessity surface carriers should not be permitted to

the Board in Docket No. 848 , and pursuant to other contracts with certificated air carricrs which are identical as to terms, conditions, and type of service to those approved;

"2. The operations proposed under the said agreement constitute air transportation by Railway Express within the meaning of section 40r(a) of the Act and are not pursuant to the air express contracts approved by the Board, or identical with such contracts as to terms, conditions, and type of service;

"3. The aforesaid agreement between Railway Express and Northwest, providing for the operation of an air freight business, violates the terms of said exemption orders, and is therefore in violation of section 401 (a) of the Act and should be disapproved under section 412(b) of the Act. . . ."

${ }^{31}$ The air express rate per 100 pounds from New York to San Francisco is \$73.68. The air freight rate is $\$ 28.10$. From New York to Chicago the rate per 100 pounds for air express is $\$ 21.49$ as contrasted with a rate of $\$ 10.35$ for air freight. These rates include pick-up and delivery charges. REA Tariff C. A. B. 70. Air Freight Rates, Freight Tariffs, Agent Johnson, C. A. B. No. 3.

${ }^{35}$ Differences in rates are not discriminatory when based upon differences in service, circumstances, and competitive conditions. See Roserts, Federal Liabilmites of Carruers 454 (2d ed. x929); Barringer and Co. v. United States, 319 U. S. I (I942); I. C. C. v. Chicago G. W. Ry. et al., 209 U. S. 108 (1907). Discrimination must ordinarily be by the same carrier or carriers. See Central R. R. of New Jersey v. United States, 257 U. S. 247 (192I). The joint nature of the air express arrangement, with the reservation of power to the multiple-service airlines contained in the Air Express Agreement to establish air express rates (see note 30, supra) while also controlling rates for competitive air freight might, however, render the airlines vulnerable to a charge of discrimination.

${ }_{38}$ "The certificated carriers contend that the differences between air freight and air express are not important and one of the duties assigned by them to ACI (Air Cargo, Inc.) is to determine when the present tariff distinction between air express and air freight can be dropped and the two services merged into a single air cargo service to be rendered under a single tariff." Air Freight Forvarder Case, opinion, stipra note 17 , at 30 . 
engage in air transportation to any greater extent than is necessary pursuant to the Act and decisions thereunder. ${ }^{37}$ Its actions are otherwise difficult of explanation unless motivated by a desire to be "all things to all men." Both the Air Freight and Air Freight Forwarder Cases involve a striking series of compromises on the part of the Board. In both cases the multiple-service carriers opposed the authorization of operating authority to any of the applicants. The Examiners in the Air Freight Case recommend the certification of six of the applicants. ${ }^{38}$ In its tentative decision the Board cut the number down to four. ${ }^{39}$ In its tentative decision the successful applicants were permitted to handle air express. In the final decision this privilege was denied them. In the Air Freight Forwarder Case only part of the authority sought by REA was granted. It was given the privilege of engaging in air express operations with "certificated" carriers. Part of this authority was then negated by the prohibition contained in the Air Freight Case against the handling by certificated cargo carriers of air express. The forwarder applicants received the authority sought. However, railroad-owned applicants, other than REA, were denied operating rights. Thus, practically all parties received something. Few came away empty handed. Some received all that was asked. The opposition of the multiple-service carriers was partially successful.

In the Air Freight Case the Board spoke of its entrustment by the Congress with a "major promotional and development responsibility," in excusing what ito intimated was lacking in the case in the way of factual proof of public convenience and necessity. It said:

Our decision must also take into account and give appropriate weight to broad considerations of future welfare related to the development of a new type of air commerce which until a comparatively recent time has received little attention.

In the Air Freight Forwarder Case it said of REA that:

Its widespread organization and extensive facilities enable it to serve the individual shipper at every point in the United States, regardless of isolation. Its specialized truck service makes every plane flight accessible. Between airport and city it operates at a much higher degree of frequency than is afforded by the air freight services of the direct carriers. Its services in pick-up and delivery are not limited to business days or business hours but extend to every hour of every day, Sunday and holidays included. In case of delay in the scheduled flights of a carrier it takes advantage of the services of any other air carrier operating between the same points. In case of flight interruption it transships

37 The Board found that: "The relationship between REA and the railroads does not raise any issue under section 408 of the Act because REA was wholly owned and controlled by the railroads prior to the adoption of the Civil Aeronautics Act, and the extent of that ownership and control has not been extended or modified since that date. In the Riailroad Control of Northeast Airlines Case, 4 C. A. B. 379 (1943), we stated that we did not believe "that Congress intended us to exercise jurisdiction over a control relationship created prior to the effective date of the Civil Acronautics Act and existing unchanged from that date forward.' Until some change in the ownership and control relationship takes place, no issue under section 408 will be raised by that relationship."

${ }^{38}$ Airnews, Inc., California Eastern Airways, Inc., Slick Airways, Inc., The Flying Tiger Line, Inc., U. S. Airlines, Inc., and Willis Air Service, Inc.

${ }^{30}$ Airnews, Inc., Slick Airways, Inc., The Flying Tiger Line, Inc., and U. S. Airlines, Inc. 
cargo on other air flights or on the fastest possible surface carrier, and where supplemental surface carriage is necessary in order for air express to reach destination shipments are often moved by trains or trucking vehicles that ordinarily do not carry surface express or cargo of any sort.

Conscientious exercise of its duty to promote and develop would seem to have dictated a full utilization by the Board of the facilities and services of REA in air property transportation.

Complete* realization of the potentialities of air property transportation will be difficult of attainment under the conditions with which the Board has encompassed it. A reappraisal of the situation by the Board or by Congress would seem to be indicated. 